\title{
A arquitetura escolar como objeto de pesquisa em História da Educação
}

\section{The architecture of schools as an object of research in History of Education}

\author{
Célia Rosângela Dantas Dórea ${ }^{1}$
}

\begin{abstract}
RESUMO
Uma das ideias norteadoras desta pesquisa consiste em encarar a organização do espaço na escola como um dos movimentos que permitem recuperar a história dos estabelecimentos de ensino, possibilitando uma nova leitura dessa ambiência escolar, leitura em que se procura identificar os fatores políticos, sociais, culturais e econômicos - que interferem na formulação e na execução das políticas educacionais que deram origem aos atuais espaços escolares. No rastro de uma trajetória acadêmica marcada pela intimidade com as questões relacionadas ao espaço escolar, discute-se o papel da organização do espaço na história da escola, destacando a atuação do educador Anísio Teixeira, em três momentos distintos, onde teve a oportunidade de implementar reformas e medidas educacionais que valorizavam o planejamento das edificações escolares: na Bahia (1924-1928), no Distrito Federal (Rio de Janeiro, 1931-1935) e como Secretário de Educação e Saúde do Estado da Bahia (1947-1951). Em síntese, eleger o espaço escolar como objeto de estudo configura-se como uma possibilidade de diálogo entre a Arquitetura e a Educação, ambas responsáveis pela organização e ocupação do espaço físico da escola, bem como com a sua utilização, além de tudo, como espaços educativos.
\end{abstract}

Palavras-chave: arquitetura escolar; História da Educação; organização do espaço escolar.

\footnotetext{
ABSTRACT

One of the guiding ideas of this research is to consider the organization of school spaces as one of the movements that allows us to recover the history

${ }^{1}$ Universidade do Estado da Bahia (UNEB), Departamento de Educação, Campus X. Rua Kaikan, s/n . Texeira de Freitas, Bahia, Brasil. CEP: 45995-000.
} 
of the educational Establishments, enabling a new reading of these school environments, one that aims at identifying the factors - political, social, cultural and economic - that interfere in the formulation and implementation of the educational policies that have originated the current school spaces. Following an academic trajectory marked by intimacy with issues related to the theme, the role of the organization of space in the history of the school is discussed, highlighting the work of educator Anísio Teixeira, in three different moments where he had the opportunity to implement educational measures and reforms that enriched the planning of school buildings: in the State of Bahia (1924-1928), in the Federal District (Rio de Janeiro, 1931-1935), and also as the Secretary of Education and Health of the State of Bahia (1947-1951). In short, the choice of school space as an object of study is configured as a possibility for dialogue between Architecture and Education, both responsible for the organization and occupation of the school physical space, as well as its use as educational spaces.

Keywords: architecture of schools; History of Education; organization of the school space.

\section{O espaço escolar como "espaço" de pesquisa}

A escola, em suas diferentes concretizações, é um produto de cada tempo, e suas formas construtivas são, além dos suportes da memória coletiva cultural, a expressão simbólica dos valores dominantes nas diferentes épocas (FRAGO; ESCOLANO, 1998, p. 47).

Eleger o espaço escolar como objeto de estudo me parece perfeitamente justificável, uma vez que a escolha de um tema de pesquisa deve "demarcar um campo específico de desejos e esforços por conhecer” (MARQUES, 1998, p. 92), ser construído pelo pesquisador como algo que tenha ligação com sua própria vida ou que nela se enraíza: "Da experiência antecedente, dos anteriores saberes vistos como insuficientes e limitadores nasce o desejo de conhecer mais e melhor a partir de um foco concentrado de atenções" (p. 92).

O espaço escolar como suporte físico da educação, ou seja, o prédio escolar propriamente dito tem despertado a minha atenção desde a década de 1980 , quando atuei como arquiteta junto à Secretaria da Educação do Estado da Bahia (1981-1988). Àquela época, vivenciei a realidade das escolas públicas de uma região do interior baiano, onde era comum deparar-se com a falta de espaços adequados para o desenvolvimento das diversas atividades pedagógicas, assim 
como o estado precário de conservação em que se encontrava a maioria dos prédios escolares.

Mais tarde, aprofundei essa experiência no desenvolvimento de minha dissertação de mestrado em área correlata, estudando as transformações físicas ocorridas nos ambientes das escolas públicas do estado de São Paulo, com base em seus Programas de Construção Escolar, desenvolvidos no período de 1977 a 1990 (DÓREA, 1992). A partir dessa abordagem, o espaço escolar configurou-se como possibilidade de diálogo entre a arquitetura e a educação, ambas responsáveis pela organização e pela ocupação do espaço físico da escola, bem como com a sua utilização, além de tudo, como espaço educativo.

Posteriormente, em minha pesquisa de doutorado intitulada Anísio Teixeira e a Arquitetura Escolar: planejando escolas, construindo sonhos, busquei direcionar o foco de interesse para a organização do espaço escolar, conciliando aquelas duas áreas do conhecimento (a arquitetura e a educação) imbricadas em minha formação acadêmica e na minha atuação profissional. Nestas circunstâncias, pareceu-me apropriado realizar uma leitura da obra do educador Anísio Teixeira, no que concerne à sua constante preocupação em dotar a escola de um espaço específico, remontando aos primórdios da década de 30, quando assumiu a Diretoria da Instrução Pública do Distrito Federal, no Rio de Janeiro, e empreendeu ampla reforma educacional, na qual tinha destaque a política de edificações escolares (DÓREA, 2003).

Devo acrescentar que meu contato inicial com a História da Educação deu-se por meio da participação no projeto "Memória da Educação na Bahia", implementado por um grupo de professores da UNEB, no qual estão envolvidos diversos campi distribuídos pelo interior baiano. Esse grupo de trabalho possibilitava a realização de seminários para discussão e redimensionamento de nossas pesquisas, ao tempo em que criava um ambiente propício que permitia refletir sobre um antigo objeto de estudo - o espaço escolar - agora sob um novo prisma.

Analogamente, no contexto da recente produção historiográfica, nota-se crescente interesse pelo estudo da escola, resultante de um novo modo de olhar e interrogar as fontes disponíveis, com ênfase na materialidade das práticas, dos objetos e de seus usos. A história da educação, solidamente radicada nas interrogações e perplexidades do presente,

passa a tematizar a perspectiva dos sujeitos dos processos investigados, trabalhando com as representações que agentes determinados fazem de si mesmos, de suas práticas, das práticas de outros agentes, de instituições - como a escola - e dos processos que as constituem (CARVALHO, 1998, p. 33). 
Ainda nessa linha, a autora acrescenta:

Com os conceitos de forma e cultura escolares, são postas em foco as práticas constitutivas de uma sociabilidade escolar e de um modo, também escolar, de transmissão cultural. Mas também são focalizados, a partir desses conceitos, os dispositivos que normatizam tais práticas: dispositivos de organização do tempo e do espaço escolar, dispositivos de normativização dos saberes a ensinar e das condutas a inculcar (CARVALHO, 1998, p. 33).

Desse suposto, de acordo com Magalhães (1998, p. 64), pode-se concluir que "a história de uma instituição educativa constrói-se entre a materialidade, a representação e a apropriação”. Assim, esta análise fundamenta-se em estudos recentes que têm dado especial destaque à questão do espaço como elemento constitutivo de uma nova concepção de escola. Autores como Viñao Frago e Escolano (1998) chamam a atenção para a importância que tem o espaço escolar como realidade social e material dentro da história da escola. Para Viñao Frago, a escola como instituição ocupa um espaço e um lugar e, como tal, possui uma dimensão educativa. "O espaço não é neutro. Sempre educa" (FRAGO; ESCOLANO, 1998, p. 75). Para Escolano, a arquitetura escolar "cumpre determinadas funções culturais e pedagógicas" e pode ser considerada como um constructo cultural e histórico, uma vez que "define o espaço em que se dá a educação formal e constitui um referente pragmático que é utilizado como realidade ou como símbolo em diversos aspectos do desenvolvimento curricular" (p. 47).

Desse novo ângulo de observação, a "escola" é tomada como objeto de investigação e passa a exigir um novo modo de olhar e interrogar as fontes tradicionalmente utilizadas, ao mesmo tempo em que abre o campo para outras fontes. Dessa forma, a história da escola requer:

uma nova leitura de fontes tradicionais - estatutos, regulamentos, discursos, memórias... - e o recurso a outras fontes até agora menos utilizadas, como autobiografias e diários, os relatórios das visitas de inspeção, as descrições do edifício, das salas de aula ou da vida escolar em geral, as memórias de arquitetos, fotografias e plantas, cadernos e diários de classe, exames, mobiliário e material de todo o tipo, calendários e horários escolares, inventários e um longo etc. de restos da realidade social e cultural das instituições educacionais (FRAGO; ESCOLANO, 1998, p. 14). 


\section{A organização do espaço escolar e a história da escola}

Segundo Escolano, "o lugar que a escola teve que ocupar na sociedade foi um ponto de especial preocupação para os reformadores dos fins do século XIX e início do século XX" (FRAGO; ESCOLANO, 1998, p. 30). Da mesma forma, no Brasil, a preocupação com um lugar específico para a escola, ou seja, com o prédio escolar propriamente dito, começou a surgir, também, a partir dessa época.

Em determinado momento, políticos e educadores passaram a considerar indispensável a existência de casas escolares para a educação de crianças, isto é, passaram a advogar a necessidade de espaços edificados expressamente para o serviço escolar. Esse momento coincide com as décadas finais do século XIX e com os projetos republicanos de difusão da educação popular (SOUZA, 1998, p. 122).

Com a instauração da República, a escola básica, como veículo para a tão desejada "reconstrução nacional", incorporou uma função salvacionista, como a única capaz de transformar o homem comum. Para Faria Filho e Vidal (2000, p. 28), em 40 anos de República, as alterações efetuadas na educação primária no Brasil foram locais e diferenciadas, decorrentes do caráter descentralizado da administração do ensino primário, e os governos estaduais tinham a responsabilidade de desenvolver a educação em seus territórios.

Observa-se que, nas décadas de 1920 e 1930, várias reformas de ensino, referenciadas nos ideais da Escola Nova, sobrevieram de forma desarticulada, em diversos estados. Junto a essas reformas, pode-se identificar algumas ações implementadas principalmente em São Paulo e no Rio de Janeiro (Distrito Federal), na tentativa de solucionar o constante problema das edificações escolares, tanto no que diz respeito ao estado precário dos prédios ocupados pelas escolas públicas, como na construção de espaços específicos para a educação primária.

Em São Paulo, a preocupação com o prédio escolar, no intuito de dar à escola um ambiente condigno, começou na última década do século XIX. Com o Decreto $n^{\circ}$ 91, de 13 de outubro de 1890, o governador provisório Prudente de Morais, insistindo nas suas ideias sobre educação popular, mandava aplicar "o saldo de 200 contos de réis, existentes no Tesouro, [...] na construção de um prédio para a Escola Normal e escolas-modelo anexas, nos terrenos que a Municipalidade havia cedido no Largo da República”. Iniciava-se, então, “a 
política da construção da casa para os estabelecimentos que o Governo mantinha ou fosse criando" (SÃO PAULO, 1934, p. 8).

Segundo a Comissão de Prédios e Instalações Escolares, que organizou a edificação escolar em São Paulo², por volta de 1919, a repartição de Engenharia Sanitária chegara a publicar um folheto em que se apresentavam "tipos de grupos escolares, escolas-reunidas e escolas singulares, a serem construídos daí por diante, em São Paulo, como padrões, e de acordo com a maior ou menor rarefação do núcleo que tivessem de servir" (SÃO PAULO, 1934, p. 25).

A partir de 1933 o problema das edificações escolares em São Paulo voltou a ser prioridade. O Código de Educação (Decreto ${ }^{0}$ 5.884, de 21 de abril de 1933) estabelecia que se criasse um serviço especial de prédios e instalações escolares e determinava que o diretor do Ensino (nessa época, o professor Fernando de Azevedo), designasse uma comissão permanente "para dar parecer sobre as condições higiênico-pedagógicas dos prédios a serem construídos e para organizar e fiscalizar a execução de um plano para a solução progressiva do problema das construções escolares" (SÃO PAULO, 1934, p. 53).

Em 1935, já era patente, por parte do governo de Armando de Salles Oliveira, a preocupação com o problema dos prédios escolares. Em solenidade de lançamento da pedra fundamental do primeiro grupo escolar da cidade de Marília, o professor Cantidio de Moura Campos, secretário da Educação, indicou o que considerava, no momento, o maior problema do ensino, ou seja, "a construção dos prédios escolares, encaradas as exigências das modernas conquistas pedagógicas..." (SÃO PAULO, 1936, p. 10).

Em 1936, o professor Almeida Júnior, então diretor do Ensino do Estado de São Paulo, para dar andamento à política de prioridade para as edificações escolares, desenvolveu intenso programa de construções escolares, com a colaboração de professores, médicos, psicólogos, engenheiros, arquitetos e técnicos, que apresentaram um estudo detalhado de todos os aspectos que deveriam ser atendidos na concepção dos edifícios escolares (SÃO PAULO, 1936, p. 42-109).

É importante destacar a concepção da professora de Psicologia Noemy da Silveira Rudolfer a respeito do papel do espaço escolar nos processos educativos. Para ela,

a renovação dos processos educativos, num sistema escolar, não depende apenas da boa vontade ou da capacidade dos que se dispõem iniciá-la.

2 Trabalho especialmente preparado para a I Exposição de Arquitetura Escolar - promovida em maio de 1934 pela Associação Brasileira de Educação, sob o patrocínio do Ministério da Educação e da Saúde Pública, nos salões da Escola Nacional de Belas Artes do Rio de Janeiro - e publicado no mesmo ano pela Diretoria Geral do Ensino do Estado de São Paulo. 
Depende também, fundamentalmente, de condições de espaço, que a tornem possível (SÃO PAULO, 1936, p. 95).

Também no Rio de Janeiro, como nos outros estados brasileiros, a solução para o problema das edificações escolares dependia de ações esparsas e do empenho individual de seus administradores. Merecem destaque duas iniciativas do final da década de 1920 e início dos anos 1930. A primeira, promovida por Fernando de Azevedo, de 1927 a 1930, a outra, entre 1931 e 1935, por Anísio Teixeira, quando estiveram à frente da Diretoria da Instrução Pública do Distrito Federal e promoveram amplas reformas educacionais que davam especial atenção às instalações escolares.

Em janeiro de 1927, ao tomar posse, Fernando de Azevedo apresentava as linhas gerais de seu programa de ideias e ressaltava a necessidade do recenseamento escolar para o conhecimento exato da situação educacional, bem como alguns aspectos particulares do seu plano de reorganização pedagógica, dentre os quais "a construção e instalação, a mais completa possível, de prédios para as escolas" (AZEVEDO, 1929, p. 15). Ao defender a ideia de uma reforma integral, destacava a importância das instalações escolares para sua efetiva implantação.

Nos discursos proferidos durante o período em que foi titular daquela Diretoria, Fernando de Azevedo demonstrava constante preocupação com a instalação da escola em local apropriado, principalmente no que concernia à questão da higiene do ensino. Para ele, a educação popular deveria começar pela proteção higiênica e formação física da população escolar (AZEVEDO, 1929 , p. 17) ${ }^{3}$. Num outro momento, acrescentava: "as edificações e instalações escolares adequadas são verdadeiros instrumentos auxiliares de um melhor sistema de profilaxia e de educação" (AZEVEDO, 1929, p. 49)

A partir de outubro de 1931, Anísio Teixeira também promoveu uma ampla reforma, privilegiando marcadamente a questão das edificações escolares. Ao assumir a Diretoria Geral de Instrução Pública do Distrito Federal, ele encontrou um cenário pouco favorável à educação pública. Anísio entendia que a educação não era apenas um fenômeno escolar, "mas um fenômeno social que se está a processar permanentemente em toda a sociedade" (TEIXEIRA, 1997, p. 255). Ele tinha consciência de que, enquanto as demais instituições exerciam "ação educativa sem plano definido e sem controle de resultados" (p. 255), a escola era, tão-somente, "a instituição conscientemente planejada para educar" (p. 255).

${ }^{3}$ Discurso de posse pronunciado a 17 de janeiro de 1927.

${ }^{4}$ Discurso de 8 de setembro de 1927, em que apresentava as bases e os princípios que nortearam o projeto de reforma do ensino primário e profissional. 
Em sua administração, foram projetados e construídos, de acordo com um plano diretor previamente estabelecido, diversos tipos de prédio escolar. Essas edificações incluíam desde o tipo Mínimo, com 3 classes; o tipo Nuclear, com 12 classes (essencialmente destinado à instrução); o tipo Platoon, com 12, 16 e 25 classes, que congregava as novas funções pedagógicas em uma mesma escola; e o tipo Playground, ou parque escolar, que deveria funcionar em conjunto com os outros tipos de escola, aliando aspectos da instrução à educação propriamente dita.

Em 1937, segundo dados apresentados por Lourenço Filho (1940), havia no Brasil 31.566 escolas isoladas e 3.176 escolas agrupadas, das quais 2.069 eram denominadas grupos escolares. Quanto aos prédios escolares, de aproximadamente 29 mil em que funcionavam escolas públicas em todo o país, apenas $16 \%$ eram públicos e especialmente construídos ou adaptados para fins escolares.

Como se vê, apesar dos ideais republicanos, o sonho de popularizar o ensino esbarrava-se em "antigo empecilho: o da ausência de prédios, mobília e material escolar adequados" (SILVA, 1997, p. 59) e, passadas as primeiras décadas da República, a escola básica havia sido facultada a poucos e era acusada de ter relegado ao abandono "milhões de analfabetos de letras e ofícios" (CARVALHO, 1989, p. 7).

Apesar de todas as dificuldades enfrentadas pela educação pública, quanto à disseminação do ensino primário e à constituição de edificações escolares adequadas nas diversas regiões do país, os estabelecimentos escolares, durante as primeiras décadas da República, convertem-se em lugar de referência para as cidades e passam a ser tomados como "modelo".

Nesse contexto, vale ressaltar a importância do "grupo escolar" na arquitetura urbana. As escolas começavam a ocupar lugares privilegiados, como "novos templos" de civilização, "templos do saber". Para Souza (1998),

o edifício escolar torna-se portador de uma identificação arquitetônica que o diferenciava dos demais edifícios públicos e civis ao mesmo tempo em que o identificava como um espaço próprio - lugar específico para as atividades de ensino e do trabalho docente (SOUZA, 1998, p. 123).

Dessa forma, segundo esta autora, o espaço escolar passava "a exercer uma ação educativa dentro e fora de seus contornos" (p. 124). Por essa época, a monumentalidade das construções dos grupos escolares passa a representar um ideal de modernidade ou de República: "a arquitetura escolar haveria, pois, de simbolizar as finalidades sociais, morais e cívicas da escola pública. O lugar 
de formação do cidadão republicano teria que ser percebido e compreendido como tal" (p. 124).

Para Faria Filho e Vidal (2000), os grupos escolares, ao serem apresentados como "modelo", permitiam aos republicanos romper com o passado imperial e "projetavam um futuro, em que, na República, o povo, reconciliado com a nação, plasmaria uma pátria ordeira e progressiva" (FARIA FILHO; VIDAL, 2000, p. 25).

Então, se a República era o lugar do homem novo, tornava-se necessário repensar esse ambiente, organizando-o, higienizando-o, ou seja, ordenando o espaço físico da cidade e, por consequência, o espaço físico da escola. Os edifícios escolares surgem, nesse momento, com uma finalidade específica - o lugar onde se processa a formação do cidadão -, e o "modelo" grupo escolar institui-se, a partir de então, como representativo de uma época.

Não obstante, os grupos escolares, assim como as reformas educacionais dos anos 1920 e 1930, tomam feições diferenciadas nos diversos estados, seja em consonância com os ideais defendidos por seus reformadores, seja pelas necessidades e dificuldades administrativas próprias de cada região.

Assim, a partir de determinado momento, tem-se uma preocupação dos órgãos públicos, por meio de seus educadores/administradores e de suas respectivas reformas educacionais, com o espaço escolar. Desde então, as edificações escolares recebem uma atenção especial e passam a ser planejadas especificamente para atender à educação. A escola passa, dessa forma, a ter a sua "casa própria", agora projetada e construída para esse fim. Nesse aspecto, ganham destaque as políticas de edificações escolares implementadas por alguns educadores, que imprimem caráter pessoal em suas administrações e um traço característico nos "modelos" de escolas ali adotados.

\section{Anísio Teixeira e a organização do espaço escolar}

Apesar de diplomado em Direito, foi pelas portas da educação que Anísio Teixeira entrou para a vida pública - e de forma algo inusitada. Em 1924, ao pleitear uma vaga de promotor público em alguma comarca nas vizinhanças de Caetité, sua cidade natal, recebeu o convite do governador Góes Calmon para assumir o cargo de inspetor geral do Ensino da Bahia. Para Nunes (2000, p. 99), “Anísio não se tornou educador com o chamado inesperado, que caíra, como semente, em terra fértil", como sugere Viana Filho (1990), mas aos poucos, quando foi descobrindo "o papel pedagógico que podia exercer na prática política e enxergando a sua atuação na educação [...]" (NUNES, 2000, p. 99). 
A partir de então, Anísio assumiu vários cargos públicos na área educacional - inspetor geral do Ensino da Bahia (1924-1928), diretor da Instrução Pública do Distrito Federal (no Rio de Janeiro, 1931-1935) e secretário de Educação e Saúde do Estado da Bahia (1947-1951), entre outros - no exercício dos quais teve a oportunidade de implementar reformas e medidas educacionais nesses estados.

Em 1924, Anísio assume a Inspetoria Geral do Ensino da Bahia. Leva consigo, nas palavras de Nunes (2000, p. 88), a familiaridade com a política sertaneja, o sentimento de católico fervoroso, a organização de pensamento e trabalho aprendida nos colégios jesuítas e os conhecimentos jurídicos adquiridos na Faculdade de Direito. Para suprir o desconhecimento para com a área em que atuaria e, segundo Abreu (1960, p.3), aconselhado pelo próprio Góes Calmon, providencia a leitura e a tradução de Méthodes américaines d'éducation, do educador belga Omer Buyse ${ }^{5}$, e procura ouvir as sugestões de Afrânio Peixoto e de Carneiro Leão (diretor da Instrução Pública do Distrito Federal). Em relatório de 1928, Anísio fala da tradução e da distribuição dessa obra aos professores, de modo a iniciá-los nos métodos ativos de educação da América do Norte, procurando mostrar o que e como se fazia para que a escola fosse verdadeiramente educativa e formadora da vontade e da inteligência da criança (TEIXEIRA, 1928a, p. 46).

Mas essa escola não era a mesma que encontrou na Bahia. Segundo Nunes (2000), à medida que "ia travando contato com um ensino público que não conhecia, um ensino muito diferente dos colégios jesuítas nos quais estudara" (p. 92), tomava conhecimento da realidade da educação pública que teria de administrar: as poucas escolas em funcionamento concentravam-se na capital e ocupavam antigas residências, muitas em ruínas; o governo não oferecia mobiliário escolar, nem o professor o adquiria; faltava material didático; os professores eram despreparados; além disso, havia a dispersão do serviço escolar, reduzido à simples alfabetização. Anísio demonstrava estar consciente dessa situação e, em algumas das soluções propostas, já vislumbrava a importância das edificações escolares para a consecução de seus objetivos.

Mas Anísio não encontraria, em seu estado natal, clima propício para desenvolver as ideias que absorvera junto ao espaço cultural norte-americano e que divulgara através de seu relatório. Mesmo assim, em meados de 1929, Anísio apresentou um conjunto de sugestões para a reorganização progressiva do sistema educacional baiano - incluindo, segundo Lima (1978), expansão do sistema escolar, reconstrução da escola primária, escolaridade pública obrigatória

5 Segundo Carvalho (2000, p. 96), a tradução correspondia à primeira parte da obra e teve como título Métodos americanos de educação geral e técnica (tradução especial para a Revista de Estudos Pedagógicos por Luiz Ribeiro de Senna em 1927). 
até o nível secundário, aprimoramento dos métodos de ensino, reorganização das escolas rurais para atender à educação adulta, reestruturação das escolas normais e dos ginásios, além de recursos financeiros e técnicos, enriquecimento dos quadros profissionais e até cursos de aperfeiçoamento no exterior, embora sem contar com o mesmo apoio que obtivera do governo anterior.

A 15 de outubro de 1931, quando assumiu a Diretoria da Instrução Pública do Distrito Federal (na época, o Rio de Janeiro), o nome de Anísio Teixeira ainda não despertava ressonância nacional, mas, segundo Lima (1978), já se tornara bem conhecido na esfera dos educadores. Após a Revolução de 30, Anísio chegara ao Rio de Janeiro "sem trabalho nem emprego", conforme suas próprias palavras em entrevista a Odorico Tavares (1992). Mas levava consigo a convicção de poder realizar "um programa de luta pela educação no Brasil" e foi "logo chamado para servir à educação no campo federal, primeiro, e depois no Distrito Federal" (ROCHA, 1992, p. 193).

No início de 1931, Anísio foi convidado por Francisco Campos, primeiro titular do recém-criado Ministério da Educação e Saúde (MES), a assumir o cargo de superintendente do Serviço Geral de Inspeção do Ensino Secundário daquele Ministério. É provavelmente dessa época o manuscrito Condições essenciais para a concessão de inspeção preliminar aos estabelecimentos particulares de ensino secundário (TEIXEIRA, 1931), em que Anísio estabelece as principais exigências referentes às edificações, às instalações e ao material didático que deveriam ser atendidas por esses estabelecimentos, nos termos do art. 45 do Decreto $\mathrm{n}^{\circ} 19.890$, de 18 de abril de 1931. Este documento trata da localização e da orientação dos prédios escolares, do terreno e do espaço para recreio; das condições do edifício (tais como material de construção e acabamento, número de pavimentos, dimensão das escadas e corredores); dos revestimentos das salas de aula e das salas especiais, com indicação de cores; das condições de ventilação e iluminação natural e artificial; das instalações higiênicas; do mobiliário; e do material didático ${ }^{6}$.

Naquele mesmo ano, Anísio foi convidado pelo prefeito Pedro Ernesto a assumir a Diretoria da Instrução Pública do Distrito Federal, onde "teve a oportunidade de conduzir importante reforma educacional [...] que atingiu, desde a escola primária à escola secundária e ao ensino de adultos, culminando com a criação de uma universidade municipal, a Universidade do Distrito Federal" (NUNES, 1999, p. 56).

Apesar de Anísio ter se preocupado com os três níveis da educação, desde o elementar até a universidade, foi na educação primária que sua reforma educacional desenvolveu-se com maior intensidade, incluindo um plano geral para

${ }^{6}$ A transcrição do referido documento encontra-se publicada em Dórea (2003, p. 234-237). 
reestruturação de toda a rede escolar, cujo crescimento passava a ser direcionado de acordo com as tendências de expansão da cidade. Havia também um plano específico para as edificações escolares.

Após a reorganização dos órgãos administrativos e depois de levantamentos estatísticos sobre a eficiência do ensino e as condições de todas as escolas do Distrito Federal, Anísio viu-se diante do desafio de resolver o problema da escassez da educação pública oferecida à população. Essa escassez ocorria tanto em quantidade, como em qualidade, mas ele considerava que, como administrador escolar, era preciso resolver primeiro o problema quantitativo. Ou seja, era preciso oferecer mais educação, sem que houvesse prejuízo substancial da qualidade.

Por essa época, havia escolas de toda ordem no Rio de Janeiro, e a transformação imediata desse quadro era uma tarefa impossível. Urgia, portanto, a implementação de "programas desiguais para situações desiguais". O administrador escolar devia se colocar diante da situação real da comunidade, "levando tanto em conta a sua geografia, quanto a sua humanidade" (TEIXEIRA, 1935, p. 106), e efetivar apenas os planos que estivessem de acordo com as condições materiais e espirituais do meio sobre os quais teria de agir.

A preocupação de Anísio em prover a escola de um ambiente que proporcionasse as mínimas condições materiais, tônica de sua administração, pode ser traduzida naquilo que para ele deveria sintetizar o papel do administrador escolar. No discurso de posse, ele fala sobre a sua conduta à frente da direção do sistema público de educação do Rio de Janeiro:

[...] O diretor do serviço educacional é, agora, o seu mais modesto operário. O mestre é quem realiza a obra de educação. O diretor é o simples servidor do mestre. Toda a administração não tem outro fim que o de dispor as condições de êxito para a obra, que é só do mestre: EDUCAR (TEIXEIRA, 1932a, p. 75-76; 1935, p. 102; 1997, p. 193).

E "dispor as condições de êxito" para a realização de sua obra educacional implicava, necessariamente, dotar a escola de condições materiais, pois, segundo suas convicções, sem instalações adequadas não poderia haver trabalho educativo e, por isso, o prédio, base física e preliminar para qualquer programa educacional, tornava-se indispensável para a realização de todos os demais planos de ensino (TEIXEIRA, 1935).

Dessa forma, em sua administração no Rio de Janeiro (1931-1935), em decorrência de "dificuldades de terreno, de localização, de condições do prédio, 
de economia e de programa educacional" (TEIXEIRA, 1935, p. 199), Anísio concebeu um plano de construções escolares adaptado às condições disponíveis. Um sistema escolar que conciliava essas dificuldades e previa edificações de duas naturezas: escolas nucleares e parques escolares. Nessa proposta inovadora, cada criança deveria frequentar regularmente as duas instalações, em turnos alternados: no primeiro turno, receberia, "em prédio adequado e econômico" (escolas nucleares ou escolas-classe), "o ensino propriamente dito"; no segundo, "em um parque escolar aparelhado e desenvolvido" (escola-parque), "sua educação propriamente social, a educação física, a educação musical, a educação sanitária e a assistência alimentar" (p. 199). Assim, as duas naturezas das edificações escolares se completariam e harmonizariam, "integrando-se em um todo equivalente ao das melhores escolas modernas do mundo" (p. 199).

Os cinco modelos, previstos no plano de construções escolares, podem ser classificados de acordo com seus programas arquitetônicos ${ }^{7}$ :

- A escola tipo Mínimo, com duas salas de aula e uma sala de ateliê e oficina, destinava-se a regiões com população escolar reduzida;

- A escola tipo Nuclear ou "escola-classe" dispunha de 12 salas de aula, além de locais apropriados para administração, secretaria e biblioteca de professores. As escolas deste tipo, constituídas exclusivamente de salas de aula comuns, devido à sua finalidade de ensino, deveriam ser complementadas com as atividades sociais, oferecidas no parque escolar, em um outro prédio e horário.

Os outros três tipos de prédios escolares obedeciam, em termos de organização, ao sistema administrativo Platoon, constituído de salas de aula comuns e salas especiais para auditório, música, recreação e jogos, leitura e literatura, ciências, desenho e artes industriais. Seu funcionamento dava-se pelo deslocamento dos alunos, em "pelotões" (daí o nome "Platoon"), pelas diversas salas, que eram cativas das disciplinas, conforme horários preestabelecidos, $\mathrm{o}$ que, para Oliveira (1991, p. 153), permitia "a maximização do rendimento dos espaços de trabalho". Convém lembrar que Anísio tomou conhecimento desse sistema nas visitas que fez a diversas escolas nos Estados Unidos, quando ficou impressionado com o funcionamento e o grau de eficiência dessas escolas.

- A escola Platoon de 12 classes era constituída de seis salas comuns de classe e de seis salas especiais (para leitura e literatura, ciências sociais, desenho e artes industriais, auditório, música e recreação e jogos e ciências). Foi projetada para atender a esse tipo de organiza-

${ }^{7}$ O relatório Educação pública: administração e desenvolvimento (TEIXEIRA, 1935) apresenta as plantas baixas e fotografias desses modelos de escolas, que podem ser conferidos em Dórea (2003). 
ção escolar, "com o mínimo de facilidades para o seu programa respectivo" (TEIXEIRA, 1935, p. 201) e, juntamente ao tipo "nuclear", deveria ter por centro o parque escolar na complementação de suas atividades;

- A escola tipo Platoon de 16 classes compunha-se de 12 salas comuns de classe e de quatro salas especiais para auditório, música, recreação e jogos, ciência e ciências sociais. Este modelo de prédio permitia o desenvolvimento de um programa de educação elementar, enriquecido com o ensino especial de ciências, artes e recreação. Segundo Teixeira (1935, p. 201), bastava-se a si mesmo, "possuindo todas as demais dependências para o funcionamento de um verdadeiro instituto de educação", mas ganharia sobremodo com o uso do parque escolar;

- A escola Platoon de 25 classes reunia 12 salas comuns de classe e 12 salas especiais distribuídas em pares para cada especialidade, amplo ginásio e todas as demais dependências de uma escola de grandes proporções. Era um prédio completo, "com todas as instalações para o funcionamento regular" (TEIXEIRA, 1935, p. 201), e perfeitamente adequado ao sistema Platoon.

É importante ressaltar que, apesar das inúmeras referências ao parque escolar (ou escola-parque) como complemento aos demais tipos de escola, no relatório de 1935, não existe registro de sua planta baixa, nem indicação de que tenha sido construído. Entretanto, alguns indícios apontam para uma escola construída à Praça Cardeal Arcoverde, em Copacabana, hoje Escola Dom Aquino Correa, como exemplar de parque escolar construído no Rio de Janeiro durante a gestão de Anísio Teixeira.

Ao final de 1935, época da sua exoneração da então Secretaria de Educação, o Rio de Janeiro contava com 28 novos prédios escolares, construídos no curto período de 1934 a $1935^{8}$. Todos os prédios escolares construídos em sua administração foram projetados por uma equipe de arquitetos da Divisão de Prédios e Aparelhamentos Escolares, chefiada por Enéas Silva, e correspondiam a programas arquitetônicos distintos, elaborados de acordo com a localização e as necessidades de cada escola. Os programas buscavam dar conta da melhor organização do espaço, para atender às exigências das modernas conquistas

${ }^{8}$ Silva (1935) refere-se a 28 prédios construídos e em construção, embora Anísio Teixeira apresente apenas a relação de 25 em seu relatório de 1935, todas estas identificadas na rede atual. As outras três escolas ausentes dessa primeira relação foram posteriormente indicadas na pesquisa de Oliveira (1991, p. 330). Atualmente, 26 escolas pertencem à rede municipal, e apenas duas à rede estadual. As pastas/arquivos referentes às escolas municipais encontram-se no Arquivo da Diretoria de Planejamento e Projetos (DPP), da Empresa Municipal de Urbanização (RioUrbe). 
pedagógicas e dos novos hábitos de higiene - pois, segundo Anísio, "alterada a função da escola", alteravam-se também a construção e as instalações, e, assim, "problemas de espaço, distribuição, higiene e iluminação" (TEIXEIRA, 1934, p. 6) modificar-se-iam conforme a modificação dos objetivos da escola pública.

Assim, em sua reforma, que tinha como centro a educação renovadora, cujas discussões já estavam em pauta desde a década anterior, o prédio escolar, ou seja, a realidade concreta desse discurso deveria atender a um novo programa:

[...] a escola já não poderia ser a escola dominantemente de instrução de antigamente, mas fazer as vezes da casa, da família, da classe social e por fim da escola, propriamente dita, oferecendo à criança oportunidades completas de vida, compreendendo atividades de estudos, de trabalho, de vida social e de recreação e jogos. Para essa escola, precisava-se, assim, de um novo currículo, um novo programa e um novo professor (TEIXEIRA, 1962, p. 21-33; 1994, p. 162).

E, logicamente, de uma nova arquitetura escolar, pois, junto a essa nova concepção de escola, haveria de surgir uma nova forma de organização do espaço escolar.

Após sua demissão, Anísio Teixeira afastou-se da vida pública por um período de 12 anos e, só em 1947, a convite do governador Otávio Mangabeira, assumiu a Secretaria de Educação e Saúde do Estado da Bahia (1947-1951) e retomou a luta pela causa da educação pública em sua terra natal.

No relatório de 1949 (TEIXEIRA, 1949), o educador apresenta ao governador da Bahia um balanço da situação em que se encontravam os serviços educacionais naquele estado e traça um plano de atuação específico para o interior e para a capital. Para o interior do Estado, além do sistema de educação elementar, com atendimento também para a zona rural, planejou um sistema de ensino médio ou secundário, que previa a construção de centros regionais de educação. Na capital, o plano escolar envolvia um sistema de escolas elementares, seguido de um conjunto de escolas secundárias de cultura geral e técnica e da escola de formação de professores em nível de ensino superior.

Mas, segundo Anísio, as escolas elementares teriam uma organização especial, constituindo os centros de educação popular que, localizados na periferia da cidade, funcionariam como núcleos de articulação de bairro, onde as funções tradicionais da escola seriam preenchidas em determinados prédios e as de educação física, social, artística e industrial, em outros, e cujo conjunto compreenderia escolas-classe e escolas-parque (TEIXEIRA, 1949). Dos 10 cen- 
tros planejados inicialmente, só foi possível a construção de um deles, o Centro Educacional Carneiro Ribeiro (CECR), localizado no bairro da Liberdade, em Salvador. Popularmente conhecido como "Escola Parque", transformou-se na obra máxima de seu idealizador e constituiu-se numa "tentativa de se produzir um modelo para a nossa escola primária” (TEIXEIRA, 1967, p. 246-253).

O discurso de Anísio Teixeira proferido em 21 de setembro de 1950, por ocasião da inauguração de três escolas-classe que integrariam o conjunto do CECR, esclarece acerca da concepção do Centro, que, segundo ele, era "o começo de um esforço pela recuperação, entre nós, da escola pública primária" e, esclarece também, sobre a organização do que ele estava a chamar de "centro de educação popular" (TEIXEIRA, 1959, p. 78-84)9':

A escola primária seria dividida em dois setores, o da instrução, propriamente dita, ou seja da antiga escola de letras, e o da educação, propriamente dita, ou seja da escola ativa. [...] A escola seria construída em pavilhões, num conjunto de edifícios que melhor se ajustassem às suas diversas funções. [...] Fixada, assim, a população escolar a ser atendida em cada centro, localizamos quatro pavilhões, como este, para as escolas que chamamos de escolas-classe, isto é, escolas de ensino de letras e ciências, e um conjunto de edifícios centrais que designamos de escola-parque, onde se distribuiriam as outras funções do centro, isto é, as atividades sociais e artísticas, as atividades de trabalho e as atividades de educação física. A escola-classe aqui está: é um conjunto de 12 salas de aula, planejadas para o funcionamento melhor que for possível do ensino de letras e ciências, com disposições para administração e áreas de estar. É uma escola parcial e para funcionar em turnos. Mas virá integrá-la a escola-parque. A criança fará um turno na escola-classe e um segundo turno na escola-parque. Nesta escola, além de locais para suas funções específicas, temos mais a biblioteca infantil, os dormitórios para 200 das 4.000 crianças atendidas pelo Centro e os serviços gerais e de alimentação. Além da reforma da escola, temos o acréscimo desse serviço de assistência, que se impõe, dadas as condições sociais (TEIXEIRA, 1959, p. 78-84).

Esse Centro, cujo projeto arquitetônico ficou a cargo dos arquitetos Diógenes Rebouças, da Bahia, e Hélio Duarte, de São Paulo, ${ }^{10}$ foi planejado para

${ }^{9}$ Esse discurso encontra-se reproduzido em Teixeira (1959, p. 78-84; 1994, p. 172-180) e Eboli (2000, p. 4-12), entre outras publicações.

${ }^{10}$ Ver, a esse respeito, o depoimento de Diógenes Rebouças, em Rocha (1992, p. 147-154), Duarte (1973) e Teixeira (1967). 
atender a um grupo de 4 mil alunos, em sua capacidade máxima. O conjunto foi constituído de quatro "escolas-classe", compostas tão-somente de salas de aula e dependências para o professor, para atender a 1.000 alunos, cada uma, em dois turnos, e uma "escola-parque" para 2 mil alunos em cada turno, em salas de música, dança, teatro, educação artística e social, salas de desenho e artes industriais, ginásio de educação física, biblioteca, restaurante, serviços gerais e residência ou internato para as chamadas "crianças abandonadas". O funcionamento se daria em turnos alternados: enquanto metade dos alunos estava na escola-parque, a outra metade distribuía-se por quatro escolas-classe; ao meio-dia, os dois grupos revezavam-se ${ }^{11}$.

A conclusão desse Centro só foi possível graças ao empenho do próprio Anísio Teixeira. Em 1952, ao ser nomeado diretor do Instituto Nacional de Estudos Pedagógicos (Inep), viabilizou um convênio de colaboração e assistência técnica com a Secretaria de Educação da Bahia para o prosseguimento e a conclusão da obra da "Escola Parque". Em 1964, com o término da construção da escola-classe número 4, o Centro foi dado por concluído, todavia, sem o orfanato.

\section{Considerações finais}

Neste estudo, procurou-se discutir o papel da organização do espaço na constituição de uma nova cultura escolar, tomando-se como referência o educador Anísio Teixeira, no que diz respeito a sua preocupação, sempre constante, em relação ao planejamento de um espaço especialmente destinado à educação. Em suas três gestões no setor da educação pública: na Bahia (1924-1928), no Distrito Federal (Rio de Janeiro, 1931-1935) e como secretário de Educação e Saúde do Estado da Bahia (1947-1951), Anísio deu ênfase especial ao planejamento das edificações escolares. Para ele, sem instalações adequadas, não poderia haver trabalho educativo, e o prédio, base física e preliminar para qualquer programa educacional, tornava-se indispensável para a realização de todos os demais planos de ensino propriamente dito (TEIXEIRA, 1935, p. 202).

Em março de 1934, por ocasião da I Exposição de Arquitetura Escolar promovida pela Associação Brasileira de Educação, no Rio de Janeiro, Anísio Teixeira proferiu palestra sobre $O$ problema do prédio escolar (TEIXEIRA, 1934), onde destacou a importância do prédio e a necessidade absoluta de sua articulação com os objetivos do ensino. Para ele,

${ }^{11}$ Esse esquema de funcionamento pode ser visualizado em Eboli (2000), Teixeira (1962) e Dórea (2003). 
existe uma relação de causa e efeito, de meios e fins, entre o prédio e a instalação escolar, de um lado, e o programa e os fins da educação, de outro lado. Pelos prédios e instalações escolares e não pelas leis e regulamentos é que se pode conhecer o verdadeiro programa de ensino de uma localidade. Está claro que depois do prédio surge o problema do professor, mas esse não pode ser resolvido antes daquele. [...] A preponderância do elemento material é tão forte que o administrador nem por um momento vacila em ajustar o seu programa às condições reais do sistema escolar [...]. Mas, uma coisa são as nossas teorias e outra as condições que nos oferecem e que trazem já consigo, as próprias teorias que encarnam. Em rigor temos todos que administrar o ensino com as doutrinas dos prédios e das instalações escolares. Prédios e instalações é que fixam os limites e marcam as diretrizes de um sistema escolar (TEIXEIRA, 1934, p. 5-6).

Posteriormente, já na década de 1950, no artigo Um presságio de progresso (TEIXEIRA, 1951), mais uma vez o educador demonstrava a convicção de que, pela arquitetura, e em particular pela arquitetura moderna, se poderia transmitir uma nova maneira de educar, de acordo com as novas concepções que embalavam o seu projeto educacional. Anísio acreditava que, pelo "gesto" da arquitetura moderna - o gesto gerando o sentimento - os prédios escolares pudessem "comunicar a educação" (TEIXEIRA, 1951, p. 175).

E, de fato, com as suas escolas, com os seus prédios especialmente projetados, com os seus programas específicos para cada tipo de escola, Anísio dava-nos o exemplo de que, também, por meio da arquitetura era possível transmitir uma nova maneira de educar.

\section{REFERÊNCIAS}

ABREU, J. Anísio Teixeira e a educação na Bahia. In: AZEVEDO, F. de et al. Anísio Teixeira: pensamento e ação. Rio de Janeiro: Civilização Brasileira, 1960. p. 1-68.

AZEVEDO, F. de. A reforma do ensino no Distrito Federal: discursos e entrevistas. São Paulo: Melhoramentos, 1929.

BRASIL. Decreto n ${ }^{\circ} 18.890$, de 18 de abril de 1931. Lei Francisco Campos. Dispõe sobre a organização do ensino secundário. Diário Official, Rio de Janeiro, 4 jun. 1931. CARVALHO, M. M. C. de. A escola e a República. São Paulo: Brasiliense, 1989. 
. Por uma história cultural dos saberes pedagógicos. In: SOUSA, C. P. de; CATANI, D. B. Práticas educativas, culturas escolares, profissão docente. São Paulo: Escrituras, 1998. p. 31-40.

. Anísio Teixeira: itinerários. Contato, Brasília, DF, Senado Federal, n. 7, abr./ jun. 2000. p. 85-101.

DÓREA, C. R. D. Escola, o espaço da educação: análise dos ambientes escolares nos programas de construção escolar do Estado de São Paulo (1977-1990). 120 f. Dissertação (Mestrado em Comunicação e Semiótica) - Pontifícia Universidade Católica de São Paulo, São Paulo, 1992.

. Anísio Teixeira e a arquitetura escolar: planejando escolas, construindo sonhos. 265 f. Tese (Doutorado em Educação: História, Política, Sociedade) - Pontifícia Universidade Católica de São Paulo, São Paulo, 2003.

DUARTE, H. Escolas-classe, escola-parque: uma experiência educacional. Monografia (Graduação em Arquitetura) - Faculdade de Arquitetura, Universidade de São Paulo, São Paulo, 1973.

EBOLI, T. Uma experiência de educação integral: Centro Educacional Carneiro Ribeiro. 4. ed. Rio de Janeiro: Gryphus, 2000. (1. ed.: 1969).

FARIA FILHO, L. M. de; VIDAL, D. G. Os tempos e os espaços escolares no processo de institucionalização da escola primária no Brasil. Revista Brasileira de Educação, São Paulo, Associação Nacional de Pós-Graduação e Pesquisa em Educação (Anped), n. 14, p. 19-34, 2000. (Número Especial: 500 anos de educação escolar).

FRAGO, A. V.; ESCOLANO, A. Currículo, espaço e subjetividade: a arquitetura como programa. Tradução de: VEIGA NETO, Alfredo. Rio de Janeiro: DP\&A, 1998.

LIMA, H. Anísio Teixeira: estadista da educação. Rio de Janeiro: Civilização Brasileira, 1978. Disponível em: <http://www.bvanisioteixeira.ufba.br/livro10/chama_livro10. $\mathrm{htm}>$. Acesso em: 8/2013.

LOURENÇO FILHO, M. B. Tendências da educação brasileira. São Paulo: Melhoramentos, 1940. (Biblioteca de Educação).

MAGALHÃES, J. Um apontamento metodológico sobre a história das instituições educativas. In: SOUSA, C. P. de; CATANI, D. B. Práticas educativas, culturas escolares, profissão docente. São Paulo: Escrituras, 1998. p. 51-69.

MARQUES, M. O. Escrever é preciso: o princípio da pesquisa. Ijuí: Unijuí, 1998. (Coleção Educação).

NUNES, C. Anísio Spínola Teixeira. In: FÁVERO, M. de L. de A.; BRITTO, J. de M. (Orgs.). Dicionário de educadores no Brasil. Rio de Janeiro: UFRJ/MEC/Inep, 1999. p. 56-64.

Anisio Teixeira: a poesia da ação. Bragança Paulista: EDUSF, 2000. 
OLIVEIRA, B. S. de. A modernidade oficial: a arquitetura das escolas públicas do Distrito Federal (1928-1940). Dissertação (Mestrado em Arquitetura) - Faculdade de Arquitetura e Urbanismo, Universidade de São Paulo, São Paulo, 1991.

ROCHA, J. A. de L. (Org.). Anísio em movimento: a vida e as lutas de Anísio Teixeira pela escola pública e pela cultura no Brasil. Salvador: Fundação Anísio Teixeira, 1992.

SÃO PAULO (ESTADO). Decreto nº 91, de 13 de outubro de 1890. Manda empregar na construção de um edificio para Escola Normal o producto da loteria, destinado á construção de uma Egreja Cathedral. Decretos e Resoluções do Governador, São Paulo, 13 out. 1890. Disponível em: <http://www.al.sp.gov.br/repositorio/legislacao/decreto/1890/ decreto\%20n.91,\%20de\%2013.10.1890.html>. Acesso em: 24/7/2013.

. Decreto n. 5.884, de 21 de abril de 1933. Institue o Codigo de Educação do Estado de São Paulo. Diário Official, São Paulo, 10 maio 1933.

. Diretoria Geral do Ensino. A edificação escolar em São Paulo. São Paulo, 1934.

. Secretaria dos Negócios da Educação e Saúde Pública. Diretoria do Ensino. Novos prédios para grupo escolar. São Paulo, 1936.

SILVA, E. Os novos prédios escolares do Distrito Federal. PDF. Revista da Diretoria de Engenharia, Rio de Janeiro, v. 4, n. 16, p. 359-365, maio 1935.

SILVA, M. C. B. da Costa e. O ensino primário na Bahia: 1889-1930. Tese (Doutorado em Educação) - Faculdade de Educação, Universidade Federal da Bahia, Salvador, 1997.

SOUZA, R. F. de. Templos de civilização: a implantação da escola primária graduada no Estado de São Paulo (1890-1910). São Paulo: UNESP, 1998.

TAVARES, O. Hierarquia para os problemas da educação. In: ROCHA, J. A. de L. (Org.). Anísio em movimento: a vida e as lutas de Anísio Teixeira pela escola pública e pela cultura no Brasil. Salvador: Fundação Anísio Teixeira, 1992. p. 188-201.

TEIXEIRA, A. S. Aspectos americanos de educação. [Salvador]: Diretoria Geral de Instrução Pública, 1928b. (Relatório de viagem na América do Norte).

. O ensino no Estado da Bahia: 1924 a 1928. Salvador: Diretoria Geral da Instrução Pública, 1928a. (Relatório Administrativo).

. Condições essenciais para a concessão de inspeção preliminar aos estabelecimentos particulares de ensino secundário. Rio de Janeiro: CPDOC/FGV, 1931. (Arquivo Anísio Teixeira, série Produção Intelectual).

. Discurso de posse do diretor geral de Instrução Pública. Boletim de Educação Pública, Rio de Janeiro, v. 2, n. 1/2, p. 75-76, jan./jun. 1932a. Disponível em: <http:// www.bvanisioteixeira.ufba.br/artigos/discurso.html>. Acesso em: 8/2013.

O sistema escolar do Rio de Janeiro, D.F. Rio de Janeiro: Diretoria Geral de Instrução Pública, 1932b. (Relatório Administrativo). 

30 mar. 1934.

. O problema do prédio escolar. Jornal do Commercio, Rio de Janeiro, p. 5-6, . Educação pública: administração e desenvolvimento. Rio de Janeiro: Diretoria Geral do Departamento de Educação, 1935. (Relatório Administrativo).

. Educação, saúde e assistência no Estado da Bahia em 1948. Salvador, 1949. (Relatório Administrativo). Disponível em: <http://www.bvanisioteixeira.ufba.br/artigos/ educacao10.html>. Acesso em: 8/2013.

. Um presságio de progresso. Habitat, São Paulo, v. 4, n. 2, p. 175, 1951. Disponível em: $<$ http://www.bvanisioteixeira.ufba.br/artigos/pressagio.html $>$. Acesso em: 8/2013.

. Centro Educacional Carneiro Ribeiro. Revista Brasileira de Estudos Pedagógicos, Rio de Janeiro, v. 31, n. 73, p. 78-84, jan./mar. 1959. Disponível em: <http://www. bvanisioteixeira.ufba.br/artigos/cecr.htm>. Acesso em: 8/2013.

. Uma experiência de educação primária integral no Brasil. Revista Brasileira de Estudos Pedagógicos, Rio de Janeiro, v. 38, n. 87, p. 21-33, jul./set. 1962. Disponível em: <http://www.bvanisioteixeira.ufba.br/artigos/uma.html>. Acesso em: 8/2013.

. A Escola Parque da Bahia. Revista Brasileira de Estudos Pedagógicos, Rio de Janeiro, v. 47, n. 106, p. 246-253, abr./jun. 1967. Disponível em: <http:/www.bvanisioteixeira.ufba.br/artigos/parque.htm>. Acesso em: 8/2013.

. Educação não é privilégio. 5. ed. Rio de Janeiro: UFRJ, 1994.

. Educação para a democracia: introdução à administração educacional. 2. ed. Rio de Janeiro: UFRJ, 1997.

VIANA FILHO, L. A. T. A polêmica da educação. Rio de Janeiro: Nova Fronteira, 1990.

Texto recebido em 03 de dezembro de 2012.

Texto aprovado em 01 de agosto de 2013. 